\title{
Electrolytic Reduction of Sulfochlorides under Controlled Potential (Rep. II)*
}

\author{
Noriake URABE** and Kazuo YASUKOCHI**
}

In a previous report, studies on the electrolytic reduction of sulfochlorides having a different substituent, and in this paper, studies on the electrolysis of other sulfochlorides having another reducible radical i.e. $\mathrm{NO}_{2}$ or $\mathrm{SO}_{2} \mathrm{Cl}$, besides a $\mathrm{SO}_{2} \mathrm{Cl}$, which shows respectively a different irreversibility polarographically were made. For the preparation of some intermediate products such as sulfinic acid, disulfoxide, disulfide and thiophenol in pure state and good yield, suitable conditions of electrolytic solution and cathode potential were researched. Especially there were no polarographic data ${ }^{3}$ for the second and third wave of $m$-nitrobenzene-sulfochloride, and therefore electrolytic conditions of this compound were decided by refering to other sulfochlorides.

The apparatus and electrolytic method were the same as that in the previous paper. ${ }^{1)}$ The amounts of electricity, which were measured by a large gas coulometer, show a good agreement with the result of graphical integration of current and time in Fig. 1 and 2.

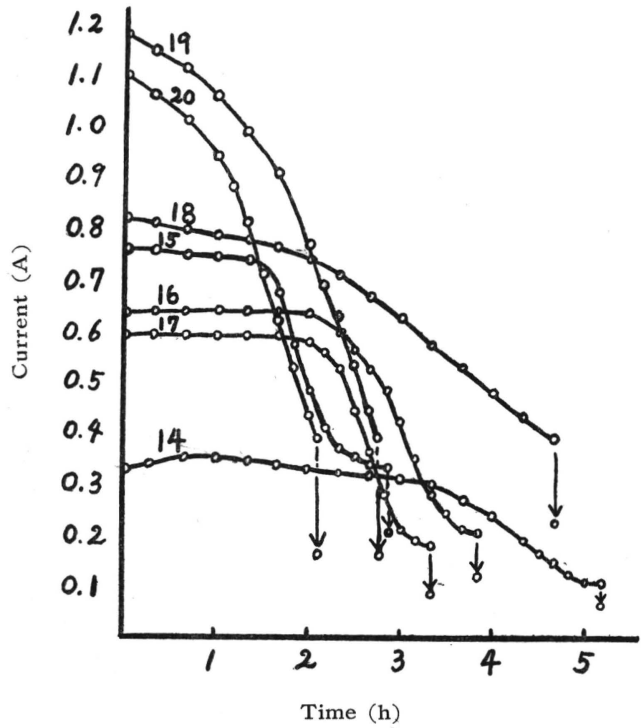

$\downarrow$ : current in the electrolytic solution, containing no sample, at the same cathode potential as in the solution of sample

Fig. 1 Current and time in electrolysis of $m$-benzene-disulfochloride.

The separation of products were operated as a principle by the method which was shown in Table 1 in the previous paper ${ }^{1)}$, but in each experiment a suitable method were employed according to the property of respective products.

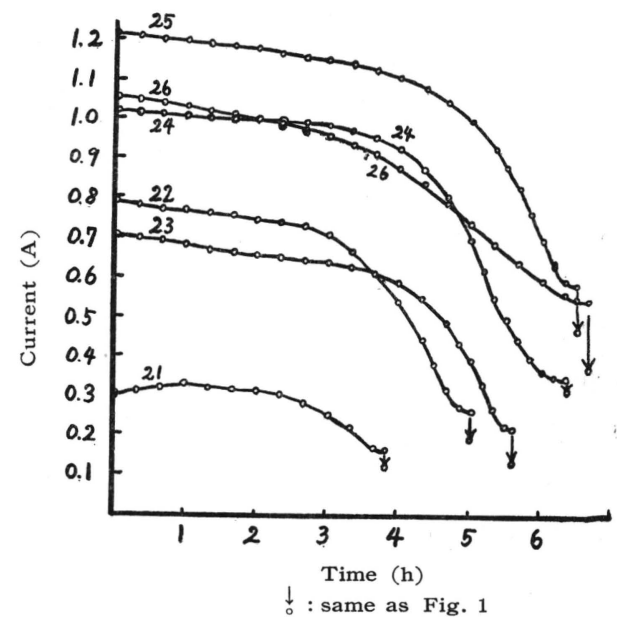

Fig. 2 Current and time in electrolysis of $m$-nitrobenzene-sulfochloride.

The confirmation of products $\left.{ }^{6}\right)$ were made as follows; $m-\mathrm{C}_{6} \mathrm{H}_{4}-\left(\mathrm{SO}_{2} \mathrm{H}\right)_{2}$ was reacted with dilute $\mathrm{H}_{2} \mathrm{SO}_{4}$ and $\mathrm{NaNO}_{2}$ to produce $m$-phenylene-disulfo-hydroxylamin $\mathrm{C}_{6} \mathrm{H}_{4}:\left(\mathrm{SO}_{2}-\mathrm{N}(\mathrm{OH})-\mathrm{SO}_{2}\right)_{2}: \mathrm{C}_{6} \mathrm{H}_{4}{ }^{2)}$,4), which decomposed at $212^{\circ} \mathrm{C}$ instead of melting; $\left.\mathrm{C}_{6} \mathrm{H}_{4}:\left(\mathrm{SO}_{2}-\mathrm{S}\right)_{2}: \mathrm{C}_{6} \mathrm{H}_{4}{ }^{5}\right)$ was reacted with conc. $\mathrm{HNO}_{3}$ to analyse $\mathrm{S}$ content, which was $37.11 \%$ while theoreticcal value is $37.21 \%$; similarly, for $\mathrm{C}_{6} \mathrm{H}_{4}$ : $\left.(\mathrm{S}-\mathrm{S})_{2}: \mathrm{C}_{6} \mathrm{H}_{4}{ }^{2)}{ }^{7}\right)$, $\mathrm{S}$ content was $45.17 \%$ while theoretical value is $45.75 \%$; for $m-\mathrm{C}_{6} \mathrm{H}_{4}$ : $(\mathrm{SH})_{2}$, it was reacted with acetic acid and lead acetate solution to produce $\mathrm{Pb}$-salt, which was coloured light orange;

* Application of Constant Potential Electrolysis to Organic Compounds (Part 5).

** Faculty of Engineering, Kumamoto University, Kyūshū, Japan

The original written in Japanese can be seen in J. Electrochem. Soc. Japan, 27, 526 (1959). 
Table 1 Reduction of $m$-benzene-disulfochloride, $m-\mathrm{C}_{6} \mathrm{H}_{4}\left(\mathrm{SO}_{2} \mathrm{Cl}\right)_{2}(0.01 \mathrm{~mol} / l, 2.75 \mathrm{~g} / l)$

\begin{tabular}{|c|c|c|c|c|c|c|c|}
\hline Exp. No. & 14 & 15 & 16 & 17 & 18 & 19 & 20 \\
\hline $\begin{array}{l}\text { Support. elect. medium } \\
\text { Added org. Solvent } \\
\text { Added inorg. Solvent } \\
\text { Cathode potential } \\
\text { Initial current }(\mathrm{mA}) \\
\text { Final current } \\
\text { Time (hr. min.) } \\
\qquad \mathrm{mA} \times \mathrm{h}\end{array}$ & $\begin{array}{l}\text { Brit. buff. } \\
\text { pH } 5.72 \\
20 \% \text { isopropyl- } \\
\text { alcohol } \\
- \\
1.00 \\
330 \\
110 \\
5 \mathrm{hr} .-10 \mathrm{~m} . \\
1120\end{array}$ & $\begin{array}{c}2 n-\mathrm{H}_{2} \mathrm{SO}_{4} \\
" \\
- \\
1.20 \\
760 \\
340 \\
2-50 \\
1170\end{array}$ & $\begin{array}{c}\text { Brit. buff. } \\
\text { pH } 5.72 \\
" \\
0.1 \mathrm{~mol} \mathrm{NaCl} \\
1.40 \\
640 \\
210 \\
3-50 \\
1640\end{array}$ & $\begin{array}{c}" \\
" \\
- \\
590 \\
180 \\
3-20 \\
1370\end{array}$ & $\begin{array}{c}" \prime \\
" \prime \\
0.1 \mathrm{~mol} \mathrm{NaCl} \\
1.68\left(\mathrm{H}_{2}\right) \\
820 \\
390 \\
4-40 \\
2010\end{array}$ & $\begin{array}{c}2 n-\mathrm{H}_{2} \mathrm{SO}_{4} \\
" \\
" \\
1.47(") \\
1180 \\
410 \\
2-45 \\
2070\end{array}$ & $\begin{array}{c}" \prime \\
\overline{\prime \prime} \\
(") \\
1100 \\
390 \\
2-05 \\
1480\end{array}$ \\
\hline $\begin{array}{l}\text { Products }(\mathrm{g}) \\
\begin{array}{l}\mathrm{R}-\left(\mathrm{SO}_{3} \mathrm{H}\right)_{2} \\
\mathrm{R}-\left(\mathrm{SO}_{2} \mathrm{H}\right)_{2} \\
\mathrm{R}:\left(\mathrm{SO}_{2}-\mathrm{S}\right)_{2}: \mathrm{R} \\
\mathrm{R}:(\mathrm{S}-\mathrm{S})_{2}: \mathrm{R} \\
\mathrm{R}:(\mathrm{SH})_{2}\end{array}\end{array}$ & $\begin{array}{r}- \\
1.8 \\
- \\
- \\
-\end{array}$ & $\begin{array}{r}- \\
1.8 \\
- \\
- \\
-\end{array}$ & $\begin{array}{r}- \\
0.1 \\
1.4 \\
- \\
-\end{array}$ & $\begin{array}{l}- \\
1.2 \\
1.4_{5} \\
+ \\
-\end{array}$ & $\begin{array}{r}- \\
0.1 \\
1.1 \\
0.3 \\
-\end{array}$ & $\begin{array}{r}- \\
0.1 \\
1.0 \\
0.4 \\
-\end{array}$ & $\begin{array}{r}- \\
1.2 \\
0.4 \\
0.1 \\
-\end{array}$ \\
\hline $\begin{array}{l}\text { Electron ratio } \\
\qquad \begin{array}{l}4 m_{1} \\
6 m_{2} \\
10 m_{3} \\
f m_{f}\end{array}\end{array}$ & $\begin{array}{r}3.49 \\
- \\
- \\
0.51\end{array}$ & $\begin{array}{r}3.49 \\
- \\
- \\
0.51\end{array}$ & $\begin{array}{r}0.19 \\
4.86 \\
- \\
0.57\end{array}$ & $\begin{array}{r}2.33 \\
1.56 \\
- \\
0.63\end{array}$ & $\begin{array}{l}0.19 \\
3.81 \\
2.13 \\
0.41\end{array}$ & $\begin{array}{l}0.19 \\
3.47 \\
2.84 \\
0.36\end{array}$ & $\begin{array}{l}2.33 \\
1.38 \\
0.7 \\
0.46\end{array}$ \\
\hline $\begin{array}{l}n^{\prime}(\mathrm{sum}) \\
n \text { (calculated from } \mathrm{m} \mathrm{A} \times \mathrm{h}) \\
\Delta A\end{array}$ & $\begin{array}{l}4.00 \\
4.18 \\
0.18\end{array}$ & $\begin{array}{l}4.00 \\
4.35 \\
0.35\end{array}$ & $\begin{array}{l}5.62 \\
6.12 \\
0.50\end{array}$ & $\begin{array}{l}4.52 \\
5.09 \\
0.57\end{array}$ & $\begin{array}{l}6.54 \\
7.49 \\
0.95\end{array}$ & $\begin{array}{l}6.86 \\
7.74 \\
0.88\end{array}$ & $\begin{array}{l}4.87 \\
5.52 \\
0.65\end{array}$ \\
\hline
\end{tabular}

$m-\mathrm{NO}_{2}-\mathrm{C}_{6} \mathrm{H}_{4}-\mathrm{SO}_{2} \mathrm{H}^{8)}$,9) was of needle-like crystal and m.p. $98^{\circ} \mathrm{C} ; m-\mathrm{NH}_{2}-\mathrm{C}_{6} \mathrm{H}_{4} \cdot \mathrm{SO}_{2}-\mathrm{S} \cdot \mathrm{C}_{6} \mathrm{H}_{4}-\mathrm{NH}_{2}{ }^{11)}$ was of needle-like crystal and decomposed to carbon at $200^{\circ} \mathrm{C}$ without melting, and changed to needle containing $2 \mathrm{HCl}$ for the purpose of analysis, which gave the result of $\mathrm{S}$ content $17.76 \%$ (to theoretical value $18.13 \%$ ) and $\mathrm{Cl}$ content $19.57 \%$ (to theoretical one $20.01 \%$ ) $m-\mathrm{NH}_{2}-\mathrm{C}_{6} \mathrm{H}_{4} \cdot \mathrm{S}-\mathrm{S} \cdot \mathrm{C}_{6} \mathrm{H}_{4}-\mathrm{NH}_{2}{ }^{2}$ ), 12) was needle and m.p. $59 \sim 60^{\circ} \mathrm{C} ; \mathrm{m}-\mathrm{NH}_{2}-\mathrm{C}_{6} \mathrm{H}_{4}-\mathrm{SH}^{13)}$ was reacted with acetic acid and lead acetate solution to produce $\mathrm{Pb}$-salt, which was coloured yellow; $m-\mathrm{NH}_{2} \cdot \mathrm{C}_{6} \mathrm{H}_{4} \cdot \mathrm{SO}_{2} \mathrm{H}^{10}$ ) decomposed at $210^{\circ} \mathrm{C}$.

Thus, the following points have been made clear;

(1) Three reduction stages, shown by the polarogram of $m$-benzene-disulfochloride and not detected by that of $m$-nitrobenzene-sulfochloride in the previous paper ${ }^{3}$, are due to the reduction to sulfinic acid, disulfoxide and disulfide. (Table 1 and 2)

(2) For the preparation of $m$-benzene-disulfinic acid, the use of $2 \mathrm{~N}_{-} \mathrm{H}_{2} \mathrm{SO}_{4}$ and alcoholic electrolyte and the cathode potential at $-1.20 \mathrm{~V}$ are suitable the use of neutral solution was unsuitable, because the electrolysis some of sulfonic acid was produced and $-1.00 \mathrm{~V}$ of the cathode potential $-1.00 \mathrm{~V}$ must be held. And the time of electrolysis in acidic solution is shorter than that in neutral one. (Exp. 14 and 15, Fig. 2)

(3) The action of repressing the first step reduction, increases with addition of $0.1 \mathrm{~mol} \mathrm{NaCl}$ and seemes to influence to the second stage reduction, and therefore the product of the third stage reduction increases. (Exp. 16, 18, 19, 23, 24, 25, 26)

(4) $m$-Benzene-resorcin begins to form after formation of $0.02 \sim 0.03 \mathrm{~mol} / l \mathrm{C}_{6}^{\prime} \mathrm{H}_{4}:(\mathrm{S}-\mathrm{S})_{2}: \mathrm{C}_{6} \mathrm{H}_{4}$. (Exp. 18, 19, 20). And it seems that the formation velocity of $m$-amino-thiophenol from disulfide was very slowly. (Exp. 24, 25, 26)

(5) It seems that the formation of disulfoxide from sulfinic acid was difficult, while the formation of disulfide from disulfoxide was easy. (Exp. 17, 20)

(6) Only in neutral solution and $-0.6 \mathrm{~V}$ of cathode potential, $m$-nitro-benzene-sulfinic acid is able to be produced. (Fig. 1 and Exp. 21) 
Table 2 Reduction of $m$-nitrobenzene-sulfochloride, $m-\mathrm{NO}_{2}-\mathrm{C}_{6} \mathrm{H}_{4}-\mathrm{SO}_{2} \mathrm{Cl}$

$(0.01 \mathrm{~mol} / l, 2.22 \mathrm{~g} / l)$

\begin{tabular}{|c|c|c|c|c|c|c|}
\hline Exp. No. & 21 & 22 & 23 & 24 & 25 & 26 \\
\hline $\begin{array}{l}\text { Support. elect. medium } \\
\text { Added org. solvent } \\
\text { Added inorg. substance } \\
\text { Cathode potential } \\
\text { Initial current }(\mathrm{mA}) \\
\text { Final current } \quad(\mathrm{mA}) \\
\text { Time (hr. min.) } \\
\quad \mathrm{mA} \times \mathbf{h}\end{array}$ & $\begin{array}{l}\text { Brit. buff. } \\
\text { pH 5.72 } \\
20 \% \text { ethyl } \\
\text { alcohol } \\
- \\
0.60 \\
300 \\
160 \\
3-50 \\
570\end{array}$ & $\begin{array}{c}2 n-\mathrm{H}_{2} \mathrm{SO}_{4} \\
" \\
- \\
1.00 \\
790 \\
310 \\
5-00 \\
2370\end{array}$ & $\begin{array}{c}\text { Brit. buff. } \\
\text { pH } 5.72 \\
" \\
0.1 \mathrm{~mol} \mathrm{NaCl} \\
1.40 \\
700 \\
220 \\
5-35 \\
2660\end{array}$ & $\begin{array}{c}0.1 n-\mathrm{HCl} \\
n \\
-\overline{50\left(\mathrm{H}_{2}\right)} \\
1020 \\
340 \\
6-20 \\
3340\end{array}$ & $\begin{array}{c}2 n-\mathrm{H}_{2} \mathrm{SO}_{4} \\
" \\
0.1 \mathrm{~mol} \mathrm{NaCl} \\
1.47(") \\
1220 \\
580 \\
6-30 \\
3440\end{array}$ & $\begin{array}{c}\text { Brit. buff. } \\
\text { pH 5.72 } \\
" \\
" \\
1.68 \text { (") } \\
1060 \\
540 \\
6-40 \\
3370\end{array}$ \\
\hline $\begin{array}{l}\text { Products }(\mathrm{g}) \\
\qquad \begin{array}{l}\mathrm{NO}_{2}-, \\
\mathrm{NH}_{2}-\mathrm{R}-\mathrm{SO}_{3} \mathrm{H} \\
\mathrm{NO}_{2}-\mathrm{R}-\mathrm{SO}_{2} \mathrm{H} \\
\mathrm{NH}_{2}-\mathrm{R}-\mathrm{SO}_{2} \mathrm{H} \\
\mathrm{NH}_{2}-\mathrm{R}-\mathrm{SO}_{2}-\mathrm{S}-\mathrm{R}-\mathrm{NH}_{2} \\
\mathrm{NH}_{2}-\mathrm{R}-\mathrm{S}-\mathrm{S}-\mathrm{R}-\mathrm{NH}_{2} \\
\mathrm{NH}_{2}-\mathrm{R}-\mathrm{SH}\end{array}\end{array}$ & $\begin{array}{l}- \\
1.5 \\
- \\
- \\
- \\
-\end{array}$ & $\begin{array}{r}- \\
- \\
1.4 \\
- \\
- \\
-\end{array}$ & $\begin{array}{r}- \\
- \\
- \\
1.20 \\
- \\
-\end{array}$ & $\begin{array}{l}- \\
- \\
- \\
- \\
1.0 \\
-\end{array}$ & $\begin{array}{l}- \\
- \\
- \\
- \\
1.0 \\
-\end{array}$ & $\begin{array}{l}- \\
- \\
- \\
- \\
1.0 \\
-\end{array}$ \\
\hline $\begin{array}{l}\text { Electron ratio } \\
\qquad \begin{array}{l}2 m_{1} \\
8 m_{2} \\
9 m_{3} \\
11 m_{4} \\
f m_{f}\end{array}\end{array}$ & $\begin{array}{r}1.60 \\
- \\
- \\
- \\
0.40\end{array}$ & $\begin{array}{r}- \\
7.21 \\
- \\
- \\
0.71\end{array}$ & $\begin{array}{r}- \\
- \\
7.71 \\
- \\
1.29\end{array}$ & $\begin{array}{r}- \\
- \\
- \\
8.87 \\
2.13\end{array}$ & $\begin{array}{r}- \\
- \\
- \\
8.87 \\
2.13\end{array}$ & $\begin{array}{r}- \\
- \\
- \\
8.87 \\
2.13\end{array}$ \\
\hline $\begin{array}{l}n^{\prime}(\text { sum }) \\
n \text { (calculated from } \mathrm{mA} \times \mathrm{h}) \\
\quad \Delta A\end{array}$ & $\begin{array}{l}2.00 \\
2.12 \\
0.12\end{array}$ & $\begin{array}{l}8.00 \\
8.83 \\
0.83\end{array}$ & $\begin{array}{l}9.00 \\
9.91 \\
0.91\end{array}$ & $\begin{array}{r}11.00 \\
12.46 \\
1.46\end{array}$ & $\begin{array}{r}11.00 \\
12.83 \\
1.83\end{array}$ & $\begin{array}{r}11.00 \\
12.58 \\
1.58\end{array}$ \\
\hline
\end{tabular}

(7) Sulfonic acid is not occured only for $m$-nitrobenzene-sulfochloride, while all other sulfochlorides produce a small amount of sulfonic acid. (Exp. 21 26)

(8) For $m$-benzene-disulfochloride, the electron ratio of the 1st, 2 nd and 3rd step reduction, calculated from the amount of products, is $3: 2: 1$ in the absence of Cl. (Exp. 20). When a combination wave of 2 nd and $3 \mathrm{rd}$ steps reduction with $\mathrm{H}_{2}$ wave appeared in polarogram of acidic solution, the ratio of 2 nd and 3 rd steps changes with the concentration of $\mathrm{Cl}^{\prime}$ as follows ; $2: 0.953$ in absence of $\mathrm{Cl}^{\prime}$ and $2 n-\mathrm{H}_{2} \mathrm{SO}_{4}$ (Exp.

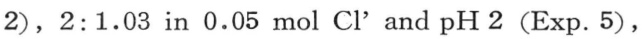
and $5: 4$ in $0.1 \mathrm{~mol} \mathrm{Cl}$ ' and $2 n-\mathrm{H}_{2} \mathrm{SO}_{4}$, while for $p$-Cl-benzene-sulfochloride (Exp. 13) the ratio was $3: 2.20$ in $0.1 \mathrm{~mol} \mathrm{Cl}$ and $2 \cdot \mathrm{H}_{2} \mathrm{SO}_{4}$. When the seperating wave of 2 nd and 3rd steps appeared in the neutral solution, the ratio is $5: 4$ even in the condition of $0.1 \mathrm{~mol}$. (Exp. 18, 19). The results as to the value of $\triangle \mathrm{A}$, is same as that of previous paper(1), (Table 1 and 2)

(Received June 4, 1958)

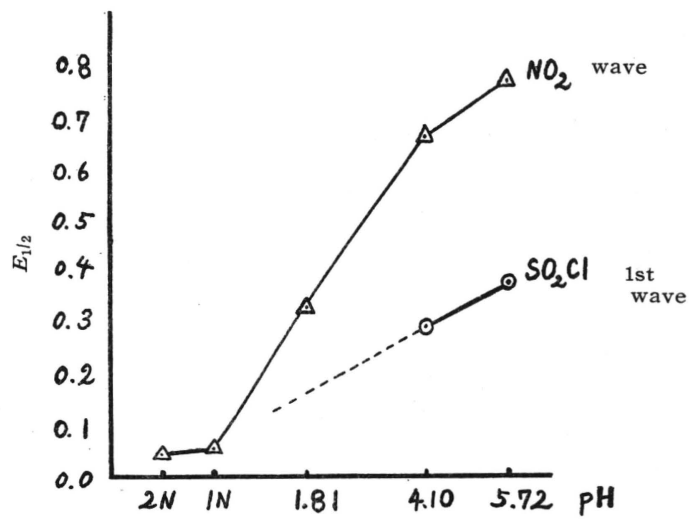

Fig. 3 Half wave potential of lst. step of $\mathrm{SO}_{2} \mathrm{Cl}$ ane $\mathrm{NO}_{2}$ v.s. $\mathrm{pH}$ of electrolytic solution.

\section{Literature :}

(1) N.Urabe, K.Yasukochi, This Journal 25, 17 (1957).

(2) Tamm, Fichter, Berichte 43, 3032 (1910).

(3) N. Urabe, K.Yasukochi, This Journal 24, 360 (1956). 
(4) T. Suzuki, J. Chem. Soc. Abst. 94, 871 (1908).

(5) Troeger u. Meine, J. Pr. Chem. 68, 318 (1903).

(6) Atsushi Fujita, "Systematic Qualitative Analysis of Organic Comp."

(7) Zincke u. Krüger, Berichte 45, 3468 (1912).

(8) Flürscheim, J. Pr. Chem, 11, 527 (1906).

(9) Limpricht, Annalen, 278, 243 (1893), Berichte 25, 3477 (1892).

(10) Limpricht, Annalen 278, 252 (1893).

(11) Limpricht, ibid. 278, 255 256 (1893).

(12) Zincke u. Miller, Berichte 46, 784 (1913).

(13) Leuckart u. Holtzapfel, J. Pr. Chem., 41, 199 (1890). 